\title{
Teeth of Polyacrodus Jaekel, 1889 from the Triassic of the Germanic Basin
}

\author{
Markus Dorka ${ }^{1}$ \\ With 1 plate and 1 table
}

\begin{abstract}
The record of Polyacrodus teeth from the Triassic of the Germanic Basin is summarized. The validity of the species Polyacrodus krafti Seilacher, 1943 and Polyacrodus keuperianus (Winkler, 1880) is discussed on the basis of new specimens, that allows to emend the diagnosis of $P$. krafti.
\end{abstract}

Key words: Teeth, Polyacrodus, Triassic, Germanic Basin.

\section{Zusammenfassung}

Die Funde von Polyacrodus-Zähnen aus der Trias des Germanischen Beckens werden zusammengefasst. Dabei wird besonders das Verhältnis der Arten Polyacrodus krafti Seilacher, 1943 und Polyacrodus keuperianus (Winkler, 1880) unter Berücksichtigung neuer Funde diskutiert. Dies führt zu einer Abwandlung der bisherigen Diagnose von P. krafti.

Schlüsselwörter: Zähne, Polyacrodus, Trias, Germanisches Becken.

\section{Introduction}

The genus Polyacrodus was erected by Jaekel in 1889 for the single species Polyacrodus polycyphus (Agassiz, 1843). Since then, several further species have been described based on isolated teeth. The following species were reported from Triassic deposits of the Germanic Basin: Polyacrodus polycyphus (Agassiz, 1843), P. krafti Seilacher, 1943, P. keuperianus (Winkler, 1880), $P$. cloacinus (Quenstedt, 1856), and P. cuspidatus (Agassiz, 1843). Polyacrodus keuperianus (Winkler, 1880) was originally named Hybodus keuperianus Winkler, 1880. Seilacher (1943: 267-269) examined new specimens and proposed, on the basis of histological features, that the species belongs to Polyacrodus rather than to Hybodus. He considered the description and the figures given by Winkler as misleading and presented a more complete description of the morphology of the species. In the same paper, Seilacher erected a new species, Polyacrodus krafti, on the basis of about 50 teeth and tooth fragments from the middle Keuper of Baden-Würt- temberg. He supposed that some teeth mentioned by Lang (1910) as teeth of Hybodus from the Obere Bunte Mergel near Stuttgart also belonged to this species. Unfortunately, Seilacher could not trace these specimens (Seilacher 1943: 271). According to Seilacher, teeth from the Schilfsandstein of Franken reported by Thürach (1888) also belong to $P$. krafti, and he also referred teeth from the Schilfsandstein of Württemberg, mentioned by Reiff (1938), to P. krafti.

The objective of this paper is to emend the diagnosis of $P$. krafti and to give a summary of the species of Polyacrodus known from the Triassic of the Germanic Basin.

\section{Material, methods, terminology}

Sometimes, it is difficult to determine whether isolated hybodont teeth belong to Polyacrodus, Lissodus or Hybodus. The reason is that few characters are available to distinguish Polyacrodus from Lissodus or Hybodus. Problems of the definition of Polyacrodus were commented on, for example, by Johnson (1981: 19, 22-23) and Rees \& Underwood (2002: 476). Consequently, in the "Comparisons" of the emended diagnosis of Polyacrodus krafti Seilacher, 1943, this species is

\footnotetext{
1 Institut für Paläontologie, Museum für Naturkunde, Invalidenstr. 43, D-10115 Berlin, Germany. Received April 2003, accepted June 2003
} 
compared also with teeth of Hybodus and Lissodus that are similar to those of $P$. krafti.

It is necessary to explain some characters used in this paper. The main cusp of a shark tooth may have a distinct protrusion labially and/or lingually, that is called a "projection" in this paper. The term "longitudinal ridge" is also used and refers to a distinct ridge that extends in the mesio-distal direction on the lower face of the crown, close to the crown/root junction. A longitudinal ridge may be separated by a peg, or in other ways. into two or more segments. Nevertheless, it is considered, in this paper, as a longitudinal ridge. "Longitudinal ridges" on a single tooth are understood here as two ridges, one on the labial side and one on the lingual side.

The specimens SMNS 56356, SMNS 86100. SMNS 86103, SMNS 86105, SMNS 86091 and SMNS 87104 were reexamined for this paper. They are deposited in the Staatliches Museum für Naturkunde Stuttgart (SMNS). Specimens from several species of Polyacrodus were collected by the author: MB. f.5608, MB. f.5609, MB. f.5613 and MB. f.5614 are from two different bonebeds of the former clay quarry Wienerberger, close to Schöningen, in Lower Saxony and are late Ladinian in age. Specimens MB. f.5603-MB. f.5606 are from a bonebed at the base of the Hauptsandstein (late Ladinian) of the Bopp quarry near Ilsfeld, Baden-Wurttemberg. Specimens MB. f. $5600-$ MB. f.5602 and MB. f.5619 are from three different layers of the Lettenkeuper (late Ladinian) of a quarry near Kirchberg an der Jagst, Baden-Württemberg. Specimen MB. f.5607 was found during a field trip at the 70th meeting of the Paläontologische Gesellschaft. The specimen is from the Lettenkeuper of the "Am Hahnritz" quarries close to Bedheim. Thuringia. Specimens MB. f.5615 and MB. f.5616 are from the Hauptsandstein of the Schumann quarry near Eschenau, Baden-Württemberg. Specimen MB. f. 5618 is from the Rhaetian of the Kirnberg near Tübingen, Baden-Württemberg. Specimens MB. f.5610-MB. f.5612 and MB. f.5617 are from the Schilfsandstein (Carnian) of the Goldersbach, near Tübingen. All the specimens collected by the author are housed in the Institut für Paläontologie des Museum für Naturkunde der Humboldt Universität Berlin.

The dimensions of several specimens of Polyacrodus are presented in Table 1.

\section{Systematic palaeontology}

Order Euselachii Hay, 1902

Superfamily Hybodontoidea Owen, 1846

Family Polyacrodontidae Glickman, 1964

Genus $\quad$ Polyacrodus Jaekel, 1889

\section{Polyacrodus krafti Seilacher, 1943}

Pl. 1: A-Q

1943 Polyacrodus krafti Seilacher, 269-271. fig. 15a-c [non figs $13,14,16-17]$
The following emended diagnosis is based on comparisons of the specimens collected by Seilacher (1943: figs 13-17) with the new material. A conclusion of this study is that SMNS 86091 (Seilacher 1943: fig. 15a-c) is the only specimen among the teeth collected by Seilacher that can be assigned to $P$. krafti with certainty. Because Seilacher (1943: 271) did not establish a holotype, SMNS 86091 is selected as the lectotype. Specimen SMNS 87104 (Seilacher 1943: fig. 13) belongs to $P$. keuperianus. The affinities of the remaining specimens are uncertain: SMNS 86103 (Seilacher 1943: fig. 14) is heavily damaged. SMNS 86100 (Seilacher 1943: fig. 17) was ground up for histological examination, and its morphology cannot be examined. Half of SMNS 86105 (Seilacher 1943: fig. 16) is embedded in matrix. This specimen will be refered to as Polyacrodus sp. 1 hereafter and is discussed in the "Comparisons section".

Diagnosis (emended from Seilacher 1943): The cusps of the teeth are pyramidal-shaped. At least one longitudinal ridge is always present. The ornamentation is weakly or moderately developed. The main cusp has a prominent projection on its labial and lingual face. This is a unique combination of characters.

Lectotype: SMNS 86091 (Pl. 1: A-B; Seilacher 1943: fig. $15 \mathrm{a}-\mathrm{c}$ ).

Locus typicus: Eisbachtal E of Gaildorf, Baden-Württemberg, SW-Germany.

Stratum typicum: Gaildorfer Bank (Dunkle Mergel).

Referred material: MB. f.5602-MB. f.5606 (Pl. 1: $\mathrm{C}-\mathrm{Q}$ ).

Description: The teeth are multicuspid and the cusps are pyramidal-shaped. The main cusp is more prominent than the lateral cusps. The ornamentation consists of a few vertical crests on the cusps. The area between two cusps shows only rarely crests. An occlusal crest and a labial and a lingual longitudinal ridge are present. The

Plate 1. Teeth of Polyacrodus krafti, P. keuperianus, P. cuspidatus and P. polycyphus. A-Q: P. krafti. A, SMNS 86091 (Lectotype), labial view. B, SMNS 86091 (Lectotype), occlusal view. C, MB. f.5605, occlusal view. D, MB. f.5602, ?labial view. E, MB. f.5602, occlusal view. F, MB. f.5606, ?labial view. G, MB. f.5606, occlusal view. H, MB. f.5606, ?lingual view. I, MB. f.5603, labial view. J. MB. f.5603, occlusal view. K. MB. f.5603, lingual view. L, MB. f.5619, labial view. M, MB. f.5619, occlusal view. N, MB. f.5619, lingual view. O, MB. f.5604, ?labial view. P, MB. f.5604, occlusal view. Q, MB. f.5604,?lingual view. R-T: $P$. keuperianus. R. MB. f.5608. labial or lingual view. S. MB. f.5608, occlusal view. T, MB. f.5612, labial view. U, $P$. cuspidatus, labial or lingual view. V. P. polycyphus, occlusal view.

The scale bars equal $1 \mathrm{~mm}$. The scale bar above fig. A represents the size of figs $\mathrm{A}-\mathrm{C}, \mathrm{F}-\mathrm{H}$ and $\mathrm{L}-\mathrm{Q}$. The scale bar above fig. $\mathrm{D}$ goes for figs $\mathrm{D}-\mathrm{E}$. The scale bar above fig. I represents the size of figs $\mathrm{I}-\mathrm{K}$ and $\mathrm{R}-\mathrm{S}$. The scale bar above fig. T represents the size only of this figure. The size of figs $U-V$ is represented by the scale bar above fig. $U$. 


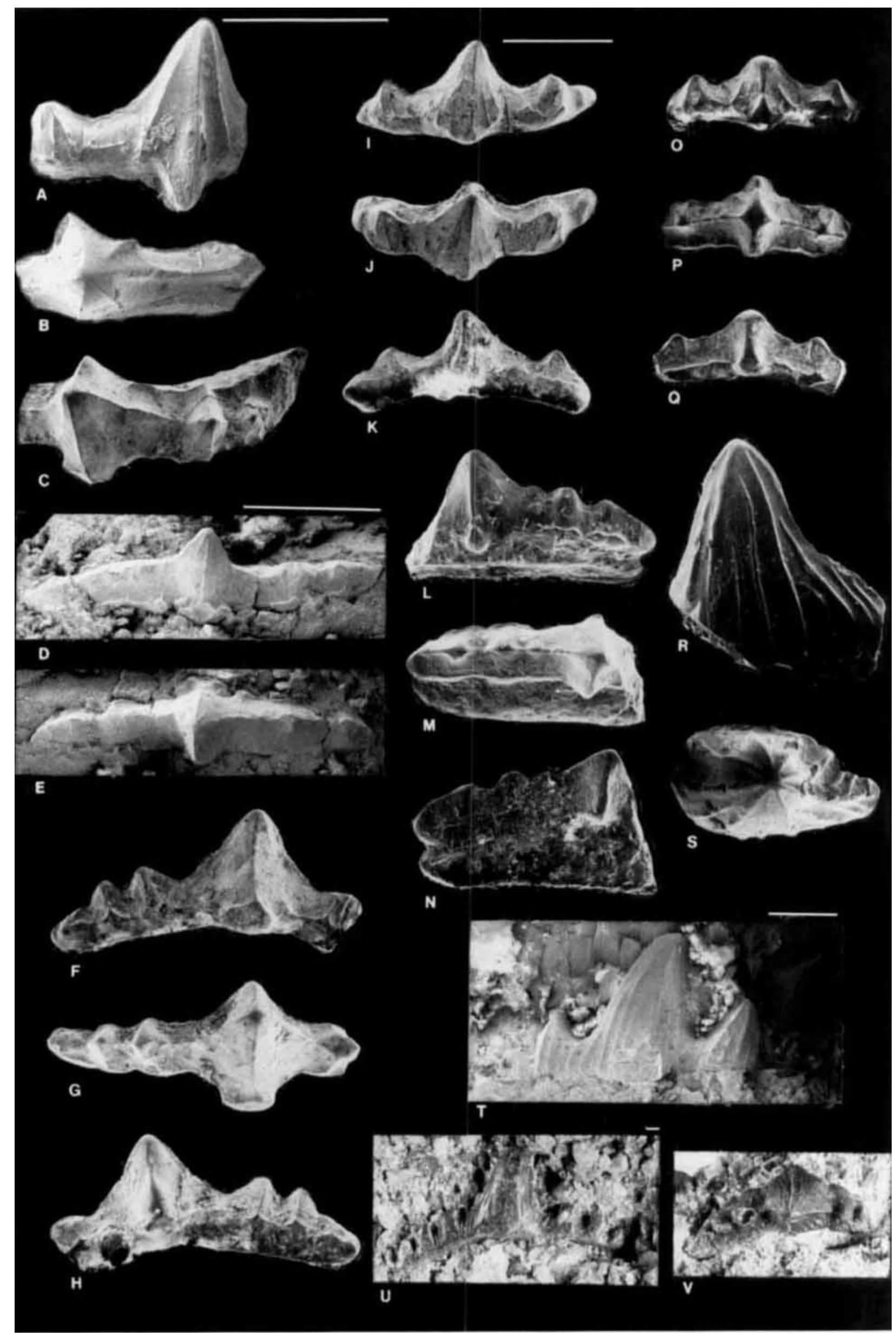


Table 1

Measurements (in $\mathrm{mm}$ ) of some tooth crowns of Polyacrodus. f The specimen is fragmented. c: The specimen is complete or nearly complete. $\mathbf{b}$ : The specimen preserves the base or a part of it.

\begin{tabular}{|c|c|c|c|c|c|}
\hline Specimen & $\begin{array}{l}\text { Species, } \\
\text { Morphotype }\end{array}$ & Preservation & Length & Depth & Width \\
\hline SMNS 86091 & P. krafti & f & - & 1.4 & - \\
\hline MB. f.5602 & P. krafti, MT 1 & c & 2.9 & 0.6 & 0.8 \\
\hline MB. f.5606 & P. krafti, MT 1 & $\mathrm{f}$ & 2.0 & 0.9 & 0.8 \\
\hline MB. f.5619 & P. krafti, MT 1 & $f+b$ & 1.4 & $0.9(b)$ & 0.6 \\
\hline MB. f.5605 & P. krafii, MT 2 & $\mathrm{f}$ & 1.8 & 0.9 & 0.9 \\
\hline MB. f.5603 & P. krafti, MT 2 & c & 2.3 & 0.9 & 0.9 \\
\hline SMNS 87104 & P. keuperianus & c & 4.3 & 6.3 & - \\
\hline MB. f.5610 & P. keuperianus & $\mathrm{c}$ & 4.7 & 2.1 & - \\
\hline MB. f.5616 & P. keuperianus & $\mathrm{c}$ & 8.1 & 3.6 & - \\
\hline MB. f.5601 & P. polycyphus & $c+b$ & $13.1(\mathrm{~b})$ & $6.8(b)$ & $3.8(b)$ \\
\hline MB. f. 5600 & P. polycyphus & $c+b$ & 12.4 (b) & $7.7(b)$ & $4.7(b)$ \\
\hline MB. f.5615 & P. polycyphus & $\mathrm{c}$ & 14.1 & - & 5.9 \\
\hline SMNS 86105 & $P$. sp. 1 & c & 2.7 & 1.2 & - \\
\hline MB. f. 5618 & P. cuspidatus & $c$ & 17.3 & 5.7 & - \\
\hline
\end{tabular}

longitudinal ridges often curve in the direction of the vertical crests, which join them basally (e.g. Pl. 1: F, G). The labial and the lingual projection are well developed. The crown consists mainly of orthodentine.

Tooth morphology shows moderate variation. The number of lateral cusps on each shoulder ranges from 1 to 3 . A few specimens, such as MB. f.5605, bear small swellings, or even nodes, at the junction of the vertical crests and the longitudinal ridge. An "independant" labial node was observed only in MB. f.5602 (Pl.1: D, E). At present, it seems appropriate to distinguish three morphotypes. The first of these has straight shoulders, sparse ornamentation and comparatively long shoulders (Pl. 1: A, B, D-H, L-N). The lectotype belongs within this morphotype. Note, that the base of the main cusp is damaged on one side, which might explain why it shows only one projection in occlusal view (Pl. 1: B). The second morphotype has shoulders that curve in the lingual direction (PI. 1: C). Several teeth of this morphotype are more strongly ornamented than teeth of the first morphotype (Pl. 1: $\mathrm{I}-\mathrm{K}$ ). In MB. f.5603 the labial face of the central cusp consists mainly of a well developed projection, while the lingual face of the central cusp is very weakly developed. This can also be observed, to a lesser degree, in the lateral cusps. The lingual projection is small. Teeth of the third morphotype have straight shoulders. They differ from teeth of the first morphotype in their stronger ornamentation (Pl. 1: O-Q). Teeth of morphotype 1 are probably from a lateral position, whereas the curved teeeth of morphotype 2 probably had a more anterior position than the presumed laterals. Teeth of morphotype 3 are rare.
They are smaller than teeth of morphotype 1 and quite symmetric. They may have occupied a position close to the symphysis, or an extralateral position.

Comparisons: Teeth of Polyacrodus krafti Seilacher, 1943 differ from teeth of Polyacrodus keuperianus (Winkler, 1880) in the presence of at least one longitudinal ridge and in having cusps that are pyramidal-shaped. The cusps of $P$. keuperianus are more slender. Teeth of $P$. krafti always have a distinct labial and lingual projection, unlike the presumed lateral teeth of $P$. keuperianus which lack this character. Presumed anterior teeth of $P$. keuperianus have only labially a projection, which differs from the projection of $P$. krafti in its very asymmetric shape: It is well rounded in the direction of one of the lateral arms, but straight in relation to the other arm. The projection is evident in, for example, specimen MB. f.5612 (Pl. 1: T), even though the base of the main cusp is damaged. Presumed anterior teeth of $P$. keuperianus have a central cusp that is deeper than the same structure in $P$. krafti and often curved in a lingual direction. Teeth of $P$. krafti are more weakly ornamented than those of $P$. keuperianus.

Polyacrodus krafti differs from specimen SMNS 86105, identified here as Polyacrodus sp. 1 (see below), in that the teeth bear less ornament. Furthermore, teeth of $P$. krafti have cusps, that appear to be more pyramidal-shaped in comparison to those of Polyacrodus sp. 1.

Teeth of Polyacrodus cuspidatus (Agassiz, 1843) (194; tab. 22a, figs 5-7) are stronger ornamented than teeth of $P$. krafti and lack longitudinal ridges. For a discussion of Polyacrodus cuspidatus see below. 
Teeth of Polyacrodus polycyphus (Agassiz, 1843) (193; tab. 24, fig. 17 and 18) often possess a labial procection (e.g. specimens MB. f.5600 and MB. f.5601; Schmid 1861: tab. 1, fig. 40), while teeth of $P$. krafti always have a labial and a lingual projection. All the morphotypes of $P$. polycyphus are more strongly ornamented than teeth of $P$. krafti and have only exceptionally a longitudinal ridge, which is not persistent.

Polyacrodus siversoni Rees, 1999 has no longitudinal ridges and the central cusp does not display prominent projections. Some presumed anterior teeth of $P$. siversoni have pronounced projections on the labial side of the first and/or second pair of lateral cusps (Rees 1999: 264, fig. 3d). Teeth of $P$. krafti have a labial and a lingual projection in the lower part of the main cusp and longitudinal ridges.

Teeth of Polyacrodus gramanni Duffin \& Thies, 1997 (pl. 3, figs 4-10; pl. 4, figs 1-6) differ from $P$. krafti in that they are more strongly ornamented, have no longitudinal ridges and lack a well-developed labial and lingual projection.

Teeth of Polyacrodus lapalomensis Johnson, 1981 (figs 75-114) lack a pronounced central cusp, lateral cusps or a labial and lingual projection. Furthermore, many teeth of this species are more strongly ornamented than teeth of $P$. krafti.

Many teeth of Polyacrodus ritchiei Johnson, 1981 bear a stronger ornamentation than teeth of P. krafti (Johnson 1981: figs 115, 116, 118, 123). Most of the teeth of $P$. ritchiei figured by Johnson (1981: figs 104-123) have a main cusp that is less developed than in teeth of $P$. krafti, except for those shown in figures 99-103. Teeth of $P$. ritchiei lack lateral cusps.

Teeth of Polyacrodus wichitaensis Johnson, 1981 are more strongly ornamented than teeth of $P$. krafti, and some do not have a pronounced main cusp (Johnson 1981: figs 138-145). Others have a well-developed main cusp (Johnson 1981: figs 124-137). The specimen shown in figures 124-127 differs from all teeth of $P$. krafti in that the crown consists principally of the main cusp. Another specimen of $P$. wichitaensis shown in figures $132-137$ is asymmetric. One of the lateral arms of the specimen bears lateral cusps, but the other lacks these. The specimen shown in figures $128-131$ is superficially similar to specimen MB. f.5603 of $P$. krafti, but the latter is longer and has a main cusp that is lower in comparison to that of the specimen shown in figures 128-131. This specimen also has an unpaired lateral cusp, while MB. f.5603 displays paired lateral cusps. Further- more, specimens of $P$. wichitaensis with a well developed main cusp seem to lack longitudinal ridges and these are also not apparent in the specimen shown in figures 124-127.

Teeth of Polyacrodus prodigialis Nesov \& Kaznyshkin, 1988 have no longitudinal ridges (Nesov \& Kaznyshkin 1988: tab. 1, figs 18a, b, 19). They also differ from the teeth of $P$. krafti in that they are more strongly ornamented and have no labial and lingual projection (Nesov \& Kaznyshkin, 1988: tab. 1, figs 18a, b and 19) as far as can be determined from figures of the damaged specimen.

All teeth of Polyacrodus balabansaiensis Nesov \& Kaznyshkin, 1988 differ from teeth of P. krafti in having no longitudinal ridges, according to the figures published by Nesov \& Kaznyshkin (1988: tab. 1, figs 1-3, 9-17). Furthermore, some of the teeth do not bear a prominent main cusp or prominent lateral cusps (Nesov \& Kaznyshkin 1988: tab. 1, figs 9a-c, 10, $11 \mathrm{a}-\mathrm{c})$. Other specimens are more strongly ornamented than $P$. krafti (Nesov \& Kaznyshkin 1988: tab. 1, figs $1 \mathrm{a}-\mathrm{c}, 2,3,13,17 \mathrm{a}-\mathrm{c})$. With some possible exceptions (Nesov \& Kaznyshkin 1988: tab. 1, figs $11 b, c, 12 b, c)$ in which the projection is not very prominent a labial and lingual projection seems to be absent in P. balabansaiensis.

Teeth of Polyacrodus tregoi Rieppel, Kindlimann \& Bucher, 1996 are more strongly ornamented than teeth of $P$. krafti and do not have longitudinal ridges. Presumed anterolateral teeth have a comparatively low main cusp and very weak developed lateral cusps (Rieppel et al. 1996: fig. 4b, c). Presumed lateral teeth do not bear any prominent cusps (Rieppel et al. 1996: fig. 4f).

Polyacrodus sp. A of Rieppel, Kindlimann \& Bucher, 1996 differs from teeth of P. krafti in the stronger tooth ornamentation and the lack of longitudinal ridges and a labial and lingual projection (Rieppel et al. 1996: fig. 3b, c).

Teeth of Polyacrodus sp. B of Rieppel, Kindlimann \& Bucher, 1996 bear a labial projection but no lingual projection. Lateral cusps are less developed than in teeth of $P$. krafti (Rieppel et al. 1996: fig. 3d-g).

Teeth of Polyacrodus pyramidalis Stensiö, 1921 differ from those of $P$. krafti in several aspects. The lateral cusps of teeth of $P$. pyramidalis are less developed than those of $P$. krafti (Stensiö 1921: text-fig. $12 \mathrm{C}-\mathrm{E}$; pl. 1, figs 23-26). In many teeth of $P$. pyramidalis, the projection is weakly developed at least on one side of the 
crown (Stensiö 1921: text-fig. 12A-C). According to the figures, many, perhaps all teeth of $P$. pyramidalis seem to lack a longitudinal ridge (Stensiö 1921: text-fig. 12A-D).

Teeth of Polyacrodus torosus Nesov \& Mertinene, 1991 are more strongly ornamented than teeth of $P$. krafti. Furthermore, teeth of $P$. torosus have many labial nodes and lateral cusps that are not prominent. The labial and lingual projection of $P$. torosus are also only weakly developed (Mertinene \& Nessov 1991: figs 1-3).

Teeth of Polyacrodus illingworthi (Dixon, 1850) differ from teeth of Polyacrodus krafti in the stronger ornamentation and the lack of longitudinal ridges (Dixon 1850: tab. 30, figs 11, 12; tab 32, fig. 9).

Teeth of Polyacrodus claveringensis Stensiö, 1932 are distinguished from teeth of $P$. krafti by the absence of longitudinal ridges (Stensiö 1932: pl. 14, fig. 2).

Teeth of Hybodus brabanticus Leriche, 1930 lack a projection or have a projection only on the labial face of the crown. Longitudinal ridges seem to be absent (Leriche 1929: 225-227, figs 4, 5).

Teeth of Hybodus brevicostatus Patterson, 1966 are distinguished from teeth of $P$. krafti by the strong ornamentation and the absence of longitudinal ridges and prominent labial and lingual projections (Patterson 1966: pl.1, fig. 3; pl. 2, figs $1-6$; pl. 3, figs $1-2$ ).

Teeth of Hybodus parvidens Woodward, 1916 often have a central cusp that is much deeper than the central cusp of teeth of $P$. krafti (Patterson 1966: figs 6A-C, 7A, 8). Low crowned morphotypes of $H$. parvidens are more similar to teeth of $P$. krafti, but like all teeth of $H$. parvidens they have a projection (called "accessory cusp" or "knob" by Patterson, 1966) only on the labial face of the crown, but not lingually (Patterson 1966: figs 7A3, 7B3). The labial projection is not always present (Patterson 1966: 297).

Teeth of Lissodus angulatus (Stensiö, 1921) are distinguished from all teeth of $P$. krafti by the lack of lateral cusps according to Birkenmajer \& Jerzmanska (1979: 25, figs 14-17).

\section{Other Polyacrodus species from the Triassic of the Germanic Basin}

It is the aim of this section to summarize and to discuss those Polyacrodus teeth from the Triassic of the Germanic Basin that do not belong to P. krafti.

\section{Polyacrodus keuperianus (Winkler, 1880)}

This species was erected on the basis of around 20 teeth from the middle Keuper near Würzburg. Seilacher (1943) described new specimens and gave a detailed description of the species. Polyacrodus keuperianus, as defined below, includes several specimens that were previously assigned to Polyacrodus krafti.

The teeth are multicuspid. The cusps are slender and only slightly pointed. In some specimens the main cusp is very pronounced in comparison to the lateral cusps. The crown is always heavily ornamented with strong ridges (Pl. 1: R, S). An occlusal crest is present. The majority of specimens are elongated and have two or three pairs of lateral cusps. The central cusp is slightly pointed. It is often curved into distal direction and sometimes in the lingual direction. These teeth do not bear a labial or lingual projection. Specimen SMNS 56356 (Seilacher 1943: fig. 12) and the specimens MB. f.7184 (Dorka 2001: fig. 1J) as well as MB. f.5607, MB. f.5608, MB. f.5609, MB. f.5610 and MB. f.5611 exhibit this morphology. Several teeth have a central cusp that is more pointed and slender than in other specimens, but does not curve in a posterior direction, although sometimes it is curved in a lingual direction. In these teeth the central cusp has a labial projection at its base. The outline of the projection, seen in occlusal view, is rounded in the direction of one lateral arm of the cusp, but straight in relation to the other arm. Specimens SMNS 87104 (Seilacher 1943: fig. 13) and MB. f.5617 represent this type. On the basis of their morphology, the teeth mentioned at first are probably lateral teeth while the others probably had a more anterior position.

Teeth of Polyacrodus keuperianus are often much larger than those of Polyacrodus krafti (see Seilacher 1943: 267, 268).

\section{Polyacrodus sp. 1}

Specimen SMNS 86105 (Seilacher 1943: 270, fig. 16) is rather problematic, because it is difficult to determine whether it belongs to Polyacrodus krafti or to Polyacrodus keuperianus. The vertical crests of its ornamentation are more strongly developed than in $P$. krafti and resemble those of $P$. keuperianus. On the other hand, the ornamentation between the cusps is very weakly developed and the specimen has a longitudinal ridge and a labial projection. Unfortunately, the specimen is embedded in matrix, so that only its 
labial face and a part of the occlusal face can be examined. This means that theoretically the shape of the cusps, especially that of the main cusp, could be different from the part that is exposed. The same goes for the ornamentation. Specimen MB. f.5603 is an example of a tooth of $P$. krafti that has an asymmetric main cusp and different ornamentation between the labial and the lingual faces of the crown.

Consequently, specimen SMNS 86105 is not assigned to $P$. krafti or $P$. keuperianus and it is considered as indetermined.

\section{Polyacrodus cuspidatus (Agassiz, 1843) and Polyacrodus cloacinus (Quenstedt, 1856)}

It is difficult to distinguish teeth of $P$. cuspidatus (Pl. 1: U) from teeth of $P$. cloacinus. Both species occur in the same layers, together with teeth of "Hybodus" minor (sensu Cuny, 1998). Quenstedt (1856: 33 and 34) erected the species Polyacrodus cloacinus based on fragmented fin spines of sharks, but applied the name to teeth in the same publication. Quenstedt (1856: 34) proposed that teeth of $P$. cloacinus differ from teeth of $P$. cuspidatus by the smoothness of the latter, but Endlich (1870: 14) suggested that the lack of ornament in P. cuspidatus was caused by abrasion, a problem previously realized by Quenstedt (1856: 34). It is difficult to understand Quenstedt"s description of $P$. cuspidatus, because the specimens of $P$. cuspidatus presented by Agassiz (1843: 194, tab. 22a, figs 5-7) are strongly ornamented. Teeth identified as $P$. cloacinus by Quenstedt (1856: tab. 2, figs 14-15) and Endlich (1870: figs 37-40) are similar to the specimens of $P$. cuspidatus identified by Agassiz, especially the specimen shown on the latters figure 6. According to Endlich (1870: 13 ), teeth of both species may bear labial nodes although they are less frequent in $P$. cuspidatus. The main difference between teeth of $P$. cuspidatus and $P$. cloacinus is that the crests of the ornamentation of $P$. cuspidatus meander. Some of the crests ramify toward the base or do not persist the entire distance from the base to the tip of the cusps (Agassiz 1843: 194; Endlich 1870: 13). In teeth assigned to $P$. cloacinus the crests are persistent and rarely meander (Endlich 1870: 13; tab. 1, figs 37-40). The inclination of the main cusp is not a character that can be utilised to distinguish the teeth of $P$. cuspidatus from those of $P$. cloacinus. In $P$. cloacinus they show some variation in the degree of inclination in the posterior direction and can be inclined in the lingual direction (Endlich 1870: 13; tab. 1, figs $37-40$ ).

The incorrect characterisation of $P$. cuspidatus by Quenstedt (1856: 34 ) and the insufficient characterisation by Endlich (1870: 13; tab. 1, figs 37-40) mean that the taxon Polyacrodus cloacinus is not valid. Teeth of $P$. cuspidatus sensu Quenstedt (1856: tab. 2, fig. 16) and Endlich (1870: tab. 1, figs 41-47) may represent a mixture of abraded teeth of Polyacrodus cuspidatus, "Hybodus" minor and teeth from the ?Norian of Saint-Nicolas-de-Port described by Duffin (1993: pl. 2, fig. 5-6) as Rhomphaiodon nicolensis.

\section{Polyacrodus polycyphus (Agassiz, 1843)}

Teeth of $P$. polycyphus (Agassiz, 1843) have cusps that are oval to pyramidal-shaped. In most of the teeth the lower face of the crown is heavily ornamented with crests that are finer than the prominent crests on the cusps. The occlusal crest is always present and may be crenulated. Two tooth morphotypes of $P$. polycyphus are recognised here. Teeth of the first morphotype (MB. f.5600 and MB. f.5601) have a straight outline in occlusal view, always a central cusp, and up to at least four pairs of lateral cusps. The ornament differs in being weaker in MB. f.5600 than in MB. f.5601. In both specimens, the ridges are thicker and less numerous on the labial side in comparison to the lingual side and the most basal part of the crown is lacking any ornamentation. A very prominent labial projection is present. In specimen MB. f.5600, the more central of the two lateral cusps on one of the lateral arms has a prominent unpaired labial node, while the other has an unpaired projection. Among the specimens figured by Jaekel (1889: pl. 9, fig. 9) is a second morphotype distinguished from the first morphortype by lateral arms that are curved lingually. Specimen MB. f.5615 ( $\mathrm{Pl}$. 1: V) is somewhat similar to the specimen figured by Jaekel in its general shape but there are some differences: the upper part of the crown is not as strongly ornamented and there are more lateral cusps, three on one lateral arm and two on the other. A pecularity of specimen MB. f.5615 is that it bears a kind of longitudinal ridge, which is developed only at the ends of the lateral arms of the crown and consists of the connected upper ends of the crests on the lower face of the crown.

Another fragmentary specimen figured by Schmid (1861: pl. 1, fig. 40) has five or six lateral cusps on one arm. The specimen is more similar 
to the first morphotype than to the second but the figures and description given by Schmid (1861) do not allow a detailed comparison.

\section{Discussion}

Teeth of Polyacrodus krafti and Polyacrodus keuperianus differ in several morphological characters listed above in the "Comparisons" section of the emended diagnosis for $P$. krafti. This emended diagnosis strengthens arguments for the assignment of Polyacrodus teeth from the Upper Ladinian and Carnian of the Germanic Basin to Polyacrodus krafti or to Polyacrodus keuperianus. One problem still remains - the assignment of SMNS 86105, identified as Polyacrodus sp. 1 in this paper. This specimen resembles teeth of $P$. keuperianus in the shape of the main cusp and in the ornamentation. But SMNS 86105 also bears a projection and a longitudinal ridge on the labial surface. These characters are absent in other specimens of $P$. keuperianus but present in $P$. krafti. The assignment of the specimen is made even more difficult because its lingual half is still embedded in matrix. This specimen gives rise to two possibilities, although neither of them questions the separation of $P$. krafti from $P$. keuperianus. If SMNS 86105 belongs to $P$. krafti then $P . k r a f t i$ can, exceptionally, bear an ornamentation similar to that of $P$. keuperianus and maybe a main cusp which resembles that of $P$. keuperianus. In this case, $P$. krafti differs from $P$. keuperianus in the possession of longitudinal ridges and a labial and lingual projections (even though the presence of a second projection in specimen SMNS 86105 is hypothetical). According to the first possibility, $P$. krafti still differs morphologically from the taxa mentioned in the "Comparisons".

The second possibility is that SMNS 86105 belongs to $P$. keuperianus. In this case, $P$. keuperianus exceptionally bears a longitudinal ridge and a labial projection (note that the labial projection of specimen SMNS 86105 is different from the projection mentioned in the description of $P$. keuperianus above in this text). In this case $P$. krafti differs from $P$. keuperianus in its sparse ornamentation and the shape of the cusps. This interpretation does not affect the differentiation of P. krafti from the other taxa.

For these reasons, the retention of two species, $P$. krafti and $P$. keuperianus, is justified at present. This idea can be additionally tested by attempting to reconstruct an hypothetical dentition with teeth of both $P$. krafti and $P$. keuperianus. This hypothetical dentition would be heterodont, because of the differences between $P$. krafti and $P$. keuperianus. Moreover, the different size and morphologies of the species make it impossible to reconstruct a functional dentition showing a monognathic or a dignathic heterodonty. The only remaining possibility is that the two species represent ontogenetic heterodonty. In this case, teeth of $P$. krafti must represent specimens younger than those bearing the $P$. keuperianus teeth. This problem can only be solved with the discovery of articulated skeletons.

Seilacher (1943: table on p. 260) proposed that $P$. keuperianus is restricted to the upper part of the Gipskeuper and P. krafti to the Schilfsandstein and the Dunkle Mergel. The present examination, which includes new specimens, shows that both species occur commonly in the Lettenkeuper and through the Dunkle Mergel. It is not possible to examine the specimens mentioned by Lang (1910), so the presence of one of the two species in the Obere Bunte Mergel is hypothetical. At present it seems that both taxa are rare in the Gipskeuper and P. krafti is remarkably rare in the Schilfsandstein and the Dunkle Mergel.

\section{Acknowledgements}

My thanks go to the following persons from the Museum für Naturkunde der Humboldt Universität Berlin: Prof. Dr. H.-P. Schultze for his generous support. Dr. D. Unwin improved the English language. I had useful discussions with Dr. $O$. Hampe. Dr. M. Aberhan and Dr. H. Hagdorn (Muschelkalkmuseum Ingelfingen) helped with literature. Dr. E. Wäsch and Mrs. G. Drescher helped with the SEM-photos. Mrs. W. Harre and Mrs. C. Radke developed the photographs. Dr. Böttcher (Staatliches Museum für Naturkunde of Stuttgart) gave permission to study specimens in the collection of the museum. Additional thanks go to the Wienerberger Ziegelindustrie $\mathrm{GmbH}$, the bmk Steinbruchbetriebe $\mathrm{GmbH} \&$ Co. KG, the Friedrich Schumann GmbH, and the Hohenloher Steinwerk GmbH \& Co.KG for permission to work in their quarries. My thanks to Dr. C. Duffin, Dr. J. Kriwet and an anonymous reviewer for reviewing the manuscript.

\section{References}

Agassiz, L. 1833-44. Recherches sur les Poissons Fossiles. 3. Contenant l'Histoire de l'Ordre des Placoïdes. - 422 pp., Petitpierre, Neuchâtel et Soleure.

Birkenmajer, K. \& Jerzmanska, A. 1979. Lower Triassic shark and other fish teeth from Hornsund, south Spitsbergen. - Studia Geologica Polonica 60: 7-37.

Cuny, G. 1998. Primitive neoselachian sharks: a survey. Oryctos 1: 3-21.

Dixon, F. 1850. The Geology and Fossils of the Tertiary and Cretaceous Formations of Sussex. 408 pp., Longman, London. 
Dorka, M. 2001. Shark remains from the Triassic of Schöningen, Lower Saxony, Germany. - Neues Jahrbuch für Geologie und Paläontologie, Abhandlungen 221 (2): 219-247.

Duffin, C. J. 1993. Late Triassic shark teeth (Chondrichthyes, Elasmobranchii) from Saint-Nicolas-de-Port (north-east France). - Belgian Geological Survey Professional Paper 264: $7-32$.

Duffin, C. J. \& Thies, D. 1997. Hybodont shark teeth from the Kimmeridgian (Late Jurassic) of northwest Germany. - Geologica et Palaeontologica 31: 235-256.

Endlich, F. M. 1870. Das Bonebed Württembergs. 30 pp., Ludwig Friedrich Fues, Tübingen.

Glikman, L. S. 1964. Klass Chondrichthyes, Podklass Elasmobranchii. In Orlov, Y. A. (ed.). Osnovy Paleontologii, 11. Agnathes, Pisces: 195-236, Nauka, Moscow (in Russian).

Hay, O. P. 1902. Bibliography and catalogue of the fossil vertebrata of North America. - Bulletin of the United States Geological Survey 179: $1-868$.

Jaekel, O. 1889. Die Selachier aus dem oberen Muschelkalk Lothringens. - Abhandlungen zur Geologischen Specialkarte von Elsass-Lothringen 3 (4): 274-332.

Johnson, G. D. 1981. Hybodontoidei (Chondrichthyes) from the Wichita - Albany Group (Early Permian) of Texas. - Journal of Vertebrate Paleontology 1 (1): 1-41.

Lang, R. 1910. Der mittlere Keuper im südlichen Württemberg. - Jahreshefte des Vereins für vaterländische Naturkunde in Württemberg 66: $1-54$.

Leriche, M. 1929. Les Poissons du Crétacé marin de la Belgique et du Limbourg hollandais (Note Préliminaire). Les resultats stratigraphiques de leur étude. - Bulletin de la Société Belge de Géologie 37: 199-299.

- 1930. Retification de nomenclature au sujet du grand Cérithe du Tuffeau de Ciply (Montien) et de l'Hybodus de la Glauconie de Lonzée (Santonien). - Bulletin de la Société Belge de Géologie 39: 102-105.

Mertinene, P. A. \& Nesov, L. A. 1991. Akuly-sclerofagi gruppy archaeoselachii i mela srednei Azii i Mongolii. Doklady Akademii Nauk Tadzhikskoi SSR 34 (1): 54-55 (in Russian).

Nesov, L. A. \& Kaznyshkin, M. H. 1988. Ezhegodnik Vsesoyuznogo Paleontologicheskogo Obshchestva 31: 160178 (in Russian).

Owen, R. 1846. Lectures on the comparative anatomy and physiology of the vertebrate animals, delivered at the
Royal College of Surgeon of England in 1844 and 1846. Part 1. Fishes. 308 pp., Longman, London.

Patterson, C. 1966. British Wealden sharks. - Bulletin of the British Museum (Natural History) 11 (7): 283-350.

Quenstedt, F. A. 1856. Der Jura. Part 1 (July 1856): 1-208. Laupp, Tübingen.

Rees, J. R. 1999. Late Cretaceous hybodont sharks from the Kristianstad Basin, south Sweden. - Neues Jahrbuch für Geologie und Paläontologie, Monatshefte 1999 (5): 257-270.

Rees, J. R. \& Underwood, C. J. 2002. The state of the shark genus Lissodus Brough, 1935, and the position of nominal Lissodus species within the Hybodontoidea (Selachii). - Journal of Vertebrate Paleontology 22 (3): 471-479.

Reiff, W. 1938. Obere bunte Estherienschichten, Schilfsandstein und Dunkle Mergel im mittleren Württemberg. Tübinger geographische und geologische Abhandlungen, Reihe 1 26: 1-195.

Rieppel, O., Kindlimann, R. \& Bucher, H. 1996. A new fossil fish fauna from the Middle Triassic (Anisian) of North Western Nevada. In Arratia, G. \& Viohl, G. (eds). Mesozoic Fishes - Systematics and Paleoecology: 219-242, Verlag Dr. F. Pfeil, München.

Schmid, E. E. 1861. Die Fischzähne der Trias bei Jena. Nova Acta Leopoldina 29: 3-42.

Seilacher, A. 1943. Elasmobranchierreste aus dem oberen Muschelkalk und Keuper Württembergs. - Neues Jahrbuch für Mineralogie, Geologie und Paläontologie Monatshefte B, 1943: 256-271, 273-293.

Stensiö, E. A. 1921: Triassic fishes from Spitsbergen. Part 1. - 307 pp., A. Holzhausen, Vienna.

- 1932. Triassic fishes from east Greenland collected by the Danish expeditions in 1921-1931. - Meddelser om Grønland 83 (3): 1-305.

Thürach, H. 1888. Ubersicht über die Gliederung des Keupers im nördlichen Franken. - Geognostische Jahreshefte 1: $75-102$.

Winkler, T. C. 1880 . Déscription des quelques restes de poissons fossiles des terrains triasiques des environs de Wurzbourg. - Archives du Musée Teyler 5: 109-149.

Woodward, A. S. 1916: The fossil fishes of the English Wealden and Purbeck Formations. Part 1. - Monographs of the Palaeontographical Society 69 (334) (for 1915): $1-48$. 